\title{
PENINGKATAN KEMAMPUAN PEMAHAMAN KONSEP DASAR PERKALIAN DENGAN MENERAPKAN MODEL PEMBELAJARAN PBL (Problem Based Learning) BERBANTUAN MEDIA PEMBELAJARAN TOLKAMA (Botol Perkalian Matematika) PADA PESERTA DIDIK KELAS II SEKOLAH DASAR
}

\author{
Syailin Nichla Choirin Attalina ${ }^{1}$, Saidatul Irfana ${ }^{2}$ \\ ${ }^{1}$ PGSD FTIK UNISNU Jepara \\ ${ }^{2}$ PGSD FTIK UNISNU Jepara \\ 호ailin@unisnu.ac.id, ㄹalds.karisma@gmail.com
}

\begin{abstract}
Some problems are often encountered in mathematics teaching and learning activities, one of which is the difficulty of the teacher delivering a material and the difficulty of students understanding the material presented by the teacher, in mathematics the learning outcomes obtained by students tend to be low, this is due to a lack of understanding of basic mathematical concepts by students. With these problems, a learning model is needed that is in accordance with the character of students and in accordance with the material being taught. In addition to the use of learning models, tools to support the teaching and learning process such as learning media can also improve understanding of basic mathematical concepts. PBL (Problem Based Learning) learning model assisted by TOLKAMA (Multiplication Bottle Mathematics) learning media can overcome these problems so as to increase the understanding of grade II elementary school students regarding the basic concept of multiplication. The method used in this research is documentation study method.
\end{abstract}

Keywords: Learning Models, Learning Media, Basic Concept of Multiplication

\begin{abstract}
ABSTRAK
Beberapa permasalahan sering ditemui dalam kegiatan belajar mengajar matematika, salah satunya yaitu sulitnya guru menyampaikan sebuah materi serta sulitnya peserta didik memahami materi yang disampaikan oleh guru, dalam mata pelajaran matematika hasil belajar yang diperoleh peserta didik cenderung rendah, hal ini dikarenakan kurangnya pemahaman konsep dasar matematika oleh peserta didik. Dengan adanya permasalahan tersebut maka dibutuhkanlah suatu model pembelajaran yang sesuai dengan karakter peserta didik dan sesuai dengan materi yang diajarkan. Selain penggunaan model pembelajaran, bantuan alat untuk menunjang proses belajar mengajar seperti media pembelajaran juga dapat meningkatkan pemahaman konsep dasar matematika. Model pembelajaran PBL (Problem Based Learning) yang berbantuan media pembelajaran TOLKAMA (Botol Perkalian Matematika) dapat mengatasi permasalahan tersebut sehingga mampu meningkatkan pemahaman peserta didik kelas II SD terkait konsep dasar perkalian. Metode yang digunakan dalam penelitian ini adalah metode studi dokumentasi.
\end{abstract}

Kata Kunci: Model Pembelajaran, Media Pembelajaran, Konsep Dasar Perkalian. 


\section{Pendahuluan}

Mata pelajaran matematika merupakan salah satu mata pelajaran yang diberikan pada seluruh peserta didik melalui kegiatan belajar mengajar di sekolah dasar. Matematika memberikan peserta didik bekal dalam kemampuan berfikir logis, kreatif dan kritis, selain itu peserta didik juga mampu menumbuhkan kemampuan bekerja sama dengan teman sebayanya. Hal tersebut diperlukan agar peserta didik dapat menjalankan kehidupan dengan keadaan yang selalu berubah dan tidak pasti.

Kegiatan Belajar Mengajar (KBM) pada mata pelajaran matematika yang ada di SD akan berjalan lebih efektif jika peserta didik lebih memahami konsep dasar terkait materi matematika yang diajarkan. Dengan adanya pemahaman konsep dasar terkait materi, maka peserta didik akan lebih mudah dalam mengikuti kegiatan belajar mengajar, selain itu peserta didik juga akan lebih berkonsentrasi saat proses belajar mengajar berlangsung.

Beberapa permasalahan sering ditemui dalam kegiatan belajar mengajar matematika diantaranya yaitu sulitnya guru menyampaikan sebuah materi, sulitnya peserta didik memahami materi yang disampaikan oleh guru, serta rendahnya hasil belajar matematika. Hal ini dikarenakan kurangnya pemahaman konsep dasar matematika oleh peserta didik. Dengan adanya permasalahan tersebut maka diperlukan suatu model pembelajaran yang sesuai dengan karakteristik peserta didik dan sesuai dengan materi yang diajarkan. Selain penggunaan model pembelajaran, bantuan alat peraga untuk menunjang proses belajar mengajar seperti media pembelajaran juga dapat meningkatkan pemahaman konsep dasar matematika.

Joice\&Weil (dalam Isjoni, 2013: 50) menyatakan bahwasannya model pembelajaran adalah suatu pola atau rencana yang telah direncanakan atau disusun sedemikian rupa serta digunakan untuk menyusun kurikulum, mengatur materi pelajaran, dan memberi petunjuk kepada pengajar di kelasnya. Model pembelajaran memiliki banyak variasi, salah satunya yaitu model pembelajaran PBL (Problem Based Learning). Rusman (2013: 230) menjelaskan bahwa model pembelajaran PBL memiliki arti pembelajaran yamg bersumber darimasalah nyata (kontekstual) sebagai acuan supaya peserta didik dapat berpikirkritis dan memiliki keterampilan dalam memecahkan masalah serta memperoleh pengetahuan. 
Asyar (2012: 8) mengemukakan bahwa media pembelajaran adalah segala macam alat yang dapat digunakan untuk menyampaikan atau menyalurkan pesan dari sumber yang disusun secara terencana, sehingga menjadikan lingkungan belajar menjadi lebih kondusif, yang mana penerimanya dapat melakukan proses belajar secara efekti dan efisien. Sedangkan media pembelajaran matematika adalah suatu alat yang digunakan oleh guru untuk mempermudah penyampaian materi matematika agar menumbuhkan minat belajar peserta didik dan dapat meningkatkan hasil belajar peserta didik. Media pembelajaran matematika digunakan untuk memudahkan peserta didik dalam memahami suatu materi pelajaran matematika dan menciptakan situasi yang lebih nyata.

Dalam pembelajaran matematika, seringkali ditemui kendala salah satunya dari persepsi peserta didik yang beranggapan bahwa matematika itu sulit hingga merekapun merasa jenuh dan pemahaman konsep dasar matematika menjadi rendah. Oleh karena itu peneliti bermaksud ingin melakukan penelitian di Sekolah Dasar terkait penggunaan model pembelajaran PBL (Problem Based Learning) berbantuan media TOLKAMA (Botol Perkalian Matematika) terhadap mata pelajaran Matematika kelas 2 SD materi perkalian.

Berdasarkan latar belakang diatas, dapat ditarik rumusan masalah sebagai berikut: 1) Apakah penggunaan model pembelajaran PBL (Problem Based Learning) dapat meningkatkan pemahaman konsep dasar matematika materi perkalian pada peserta didik kelas II Sekolah Dasar? 2) Apakah penggunaan media pembelajaran TOLKAMA (Botol Perkalian Matematika) dapat meningkatkan pemahaman konsep dasar matematika materi perkalian pada peserta didik kelas II Sekolah Dasar?

Adapun tujuan dari penelitian ini, yaitu: 1) Untuk meningkatkan pemahaman konsep dasar matematika materi perkalian pada peserta didik kelas II Sekolah Dasar menggunakan model pembelajaran PBL (Problem Based Learning). 2) Untuk meningkatkan pemahaman konsep dasar matematika materi perkalian pada peserta didik kelas II Sekolah Dasar menggunakan media pembelajaran TOLKAMA (Botol Perkalian Matematika).

Penelitian ini didikung oleh penelitian yang telah dilaksanakan oleh Budi Febriyanto, dkk. (2018) yang berjudul "Peningkatan Pemahaman Konsep Matematis Melalui Penggunaan Media Kantong Bergambar pada Materi Perkalian 
Bilangan di Kelas II Sekolah Dasar" memiliki tujuan dari penelitiannya yaitu meningkatkan pemahaman konsep matematis peserta didik. Hasil penelitian menunjukkan bahwa penggunaan media kantong bergambar dapat meningkatkan pemahaman konsep matematis peserta didik kelas II SDN Simpeureum I. Persamaan antara penelitian yang telah dilaksanakan oleh Budi Febriyanto, dkk. dengan penelitian yang akan dilaksanakan oleh penulis adalah metode penelitian yang digunakan yaitu Penelitian Tindakan Kelas (PTK), tujuan dari kedua penelitian ini sama yaitu untuk meningkatkan pemahaman konsep dasar matematika peserta didik kelas II di sekolah dasar berbantuan media pembelajaran. Sedangkan perbedaan antara dua penelitian ini yaitu: Media pembelajaran yang digunakan dalam penelitian Budi Febriyanto, dkk adalah media kantong bergambar, sedangkan media yang akan digunakan oleh peneliti adalah media TOLKAMA (Botol Perkalian Matematika). Model pembelajaran yang digunakan untuk mengajar dalam penelitian Budi Febriyanto, dkk tidak dijelaskan lebih spesifik, sedangkan dalam penelitian yang akan peneliti laksanakan menggunakan model pembelajaran PBL (Problem Based Learning).

Penelitian ini juga didikung oleh penelitian yang telah dilaksanakan oleh oleh Fahrudin dkk (2018) dengan judul "Peningkatan Pemahaman Konsep Matematika Melalui Realistic Mathematic Education Berbantu Alat Peraga Bongpas" yang memiliki tujuan penelitian untuk mendeskripsikan peningkatan kemampuan pemahaman konsep matematika, keterampilan mengajar guru dalam mengelola pembelajaran matematika dan aktivitas belajar siswa menggunakan model Realistic Mathematic Education berbantu alat peraga BongPas. Hasil penelitian menunjukkan kemampuan pemahaman konsep matematika pada siklus I yaitu $35,7 \%$ dengan kriteria kurang dan pada siklus II yaitu 78,5\% dengan kriteria baik. Persamaan antara penelitian yang telah dilaksanakan Fahrudin dengan penelitian yang akan dilaksanakan oleh penulis yaitu sama-sama menggunakan penelitian tindakan kelas untuk meningkatkan pemahaman konsep peserta didik sekolah dasar. Sedangkan perbedaannya yaitu penelitian yang dilaksanakan oleh Fahrudin menggunakan model Realistic Mathematic Education berbantu alat peraga BongPas sedangkan pada penelitian yang akan dilaksanakan oleh peneliti menggunakan model PBL (Problem Based Learning) berbantuan media pembelajaran TOLKAMA. 


\section{Pembahasan}

Kegiatan pembelajaran matematika selalu menjadi pembelajaran yang kurang disukai oleh peserta didik. Hal itu dikarenakan matematika dianggap sebagai suatu pembelajaran yang menakutkan dan membuat peserta didik tidak tertarik mengikuti pembelajaran matematika. Namun, apabila peserta didik memahami konsep dasar materi matematika akan memudahkan mereka dalam memahami materi matematika berikutnya. Untuk memahamkan konsep dasar tentunya diperlukan model pembelajaran dan media pembelajaran yang interaktif agar menarik perhatian peserta didik.

Dalam hal ini penulis bermaksud mengadakan penelitian menggunakan model pembembelajaran PBL berbantuan media pembelajaran Tolkama untuk meningkatkan pemahaman konsep dasar perkalian pada peserta didik kelas II di sekolah dasar. Penulis berharap peserta didik dapat antusias dan bergairah belajar dengan melakukan kegiatan berhitung menggunakan media Tolkama dan berdiskusi dengan teman sekelompoknya. Peserta didik juga dapat berkompetisi dengan kelompok lain dan saling menanggapi hasil diskusi kelompok lain. Sehingga nantinya peserta didik akan menemukan pengalaman baru dalam melakukan kegiatan pembelajaran matematika dan tidak membenci lagi pembelajaran matematika.

\section{Model Pembelajaran PBL (Problem Based Learning)}

PBL (Problem Based Learning) merupakan salah satu model pembelajaran yang dapat digunakan oleh guru untuk melaksanakan pembelajaran yang menarik dan menjadikan pembelajaran lebih bermakna bagi peserta didik. PBL sendiri menurut Ngalimun (2014:89) yaitu kegiatan pembelajaranyang dilaksanakan dengan berdasarkan suatu masalah, PBL juga salah satu model pembelajaran yang inovatif dan dapat memberikan kondisi belajar aktif kepada peserta didik. Selajan dengan hal tersebut Virginia dan Wasitohadi (2016: 103) mengemukakan bahwa model PBL (Problem Based Learning) adalah salah satu model pembelajaran yang inovatif dengan diberi awalan pemberian masalah atau topik masalah kepada peserta didik, yang mana masalah tersebut dialami oleh peserta didik dalam kehidupan sehari-hari mereka, selain itu peserta didik juga dapat 
bekerja sama dengan kelompok untuk menyelesaikan permasalahan tersebut sehingga peserta didik dapat menemukan pengetahuan baru. Berdasarkan pendapat para ahli diatas dapat disimpulkan bahwa model pembelajaran PBL (Problem Based Learning) adalah model pembelajaran yang meminta peserta didik mendiskusikan sebuah masalah terkait materi pembelajaran yang dijumpainya dalam kehidupan sehari-hari dan mendiskusikannya bersama kelompoknya, sehingga peserta didik menemukan pengetahuan baru.

Setiap model pembelajaran pastinya memiliki langkah-langkah dalam pelaksanaannya, begitu juga dengan model pembelajaran PBL. Berikut ini adalah sintaks (langkah-langkah) pelaksanaan model pembelajaran PBL menurut Wahidmurni (2017) :

Tabel 1. Sintaks Model PBL

\begin{tabular}{|c|c|c|c|}
\hline No. & Pendidik & Peserta Didik & Keterangan \\
\hline 1 & $\begin{array}{l}\text { Memperkenalkan } \\
\text { masalah }\end{array}$ & $\begin{array}{l}\text { Mengamati } \\
\text { Memperoleh masalah } \\
\text { dengan menyimak } \\
\text { penjelasan guru, dan } \\
\text { mendiskusikan } \\
\text { kelompoknya. dalam }\end{array}$ & $\begin{array}{l}\text { Guru memberi } \\
\text { bimbingan untuk } \\
\text { memastikan } \\
\text { bahwa masalah } \\
\text { dapat dipahami } \\
\text { oleh peserta } \\
\text { didik. }\end{array}$ \\
\hline 2 & $\begin{array}{l}\text { Memantau dan } \\
\text { memberikan umpan balik }\end{array}$ & $\begin{array}{l}\text { Menanya } \\
\text { Dalam hal ini, siswa dalam } \\
\text { kelompoknya saling } \\
\text { bertanya jawab untuk } \\
\text { mengidentifikasikasi } \\
\text { kebutuhan penelitian dan } \\
\text { membuat agenda aksi untuk } \\
\text { setiap anggota kelompok } \\
\text { hasilnya dalaha rumusan } \\
\text { masalah. }\end{array}$ & $\begin{array}{l}\text { Guru } \\
\text { memastikan } \\
\text { bahwa masalah } \\
\text { yang } \\
\text { dirumuskan } \\
\text { peserta didik } \\
\text { sudah sesuai } \\
\text { atau layak dikaji. }\end{array}$ \\
\hline 3 & $\begin{array}{l}\text { Memantau dan } \\
\text { memberikan umpan balik }\end{array}$ & $\begin{array}{l}\text { Mengumpulkan data atau } \\
\text { mencoba } \\
\text { Kegiatannya yakni } \\
\text { mengumpulkan } \\
\text { data/informasi dari berbagai } \\
\text { sumber seperti literatur, } \\
\text { artikel dalam internet atau } \\
\text { surat kabar. Informasi atau } \\
\text { narasumber, resonden atau } \\
\text { sumber lain. }\end{array}$ & $\begin{array}{l}\text { Guru } \\
\text { memastikan } \\
\text { bahwa peserta } \\
\text { didik bekerja } \\
\text { dengan baik. }\end{array}$ \\
\hline
\end{tabular}


Syailin Nichla Choirin Attalina dan Saidatul Irfana : Peningkatan Kemampuan Pemahaman Konsep Dasar Perkalian Dengan Menerapkan Model Pembelajaran ...

4
Memantau
dan memberikan umpan balik

5

Memantau memberikan umpan balik

6

Merayakan hasil kerja

Memberi penghargaan

atas keterlibatan aktif peserta didik.

\section{Media Pembelajaran Tolkama (Botol Perkalian Matematika)}

Media pembelajaran Tolkama merupakan media pembelajaran interaktif yang dapat bermanfaat untukmeningkatkan pemahaman konsep dasar perkalian pada peserta didik kelas 2 Sekolah Dasar. Media pembelajaran Tolkama sendiri terbuat dari barang bekas yakni botol minum bekas dan kardus bekas. Selain itu kertaskerta hias atau spidol warna dapat dimanfaatkan untuk mempercantik bentuk dari media tolkama tersebut.

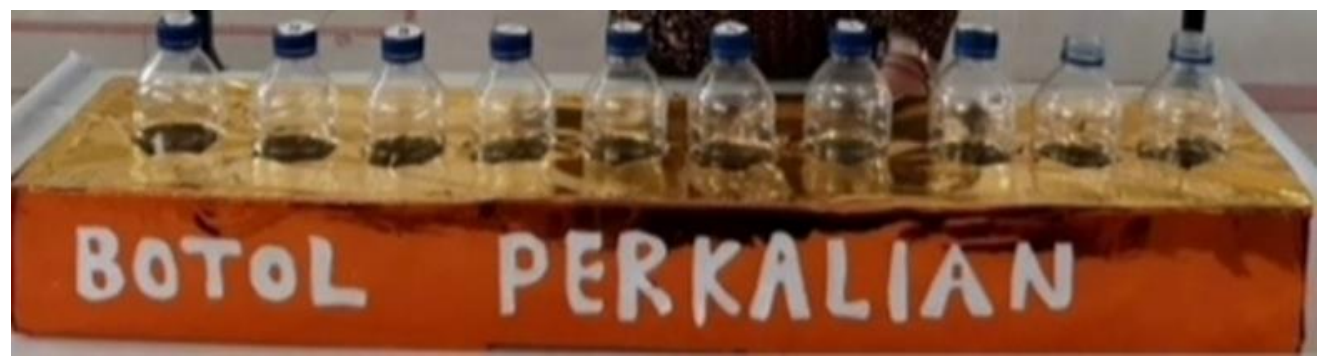

\section{Gambar 1. Media Pembelajaran Tolkama}

Cara membuat media Tolkama tidaklah sulit, langkahnya yaitu:

1. Botol bekas air mineral dipotong menggunakan cutter. Cukup ambil bagian atasnya.

2. Setelah dipotong susun botol tersebut secara mendatar menjadi 10 bagian dan letakkan di atas permukaan kardus bekas. Atur jarak antara botolnya, kemudian buat lubang sebesar ukuran botol.

3. Potong kardus dengan menggunakan cutter menyesuaikan dengan 
panjang botol yang tersusun.

4. Buat balok, dengan bagian atas balok adalah kardus yang telah dilubangi dan salah satu sisi tinggi pada panjang balok tidak ditutup dengan kardus.

5. Permukaan kardus pada balok ditutup dengan skotlet kemudian pada bagian tepi balok diberi list.

6. Buat laci yang disesuaikan dengan balok yang telah dibuat dimana bagian balok yang tidak ditutup dengan kardus merupakan bagian muka laci. Kemudian diberi tarikan laci.

7. Pada laci buatlah sekat yang dapat dibongkar pasang. Sekat tersebut disesuaikan dengan tiap lubang yang ada pada balok.

8. Pasangkan laci, botol dimasukan ke dalam lubang dan buatlah hiasan semenarik mungkin.

Sedangkan untuk cara penggunaannya sebagai berikut:

1. Guru menyajikan contoh perkalian dua bilangan, yakni $3 \times 4$.

2. Ambillah batuan kecil sebanyak 4 batu untuk dimasukkan kedalam botol pertama.

3. Ambil 4 batu kecil lagi kemudian masukkan ke botol yang kedua.

4. Ambil 4 batu kecil dan masukkan kembali kebotol yang ketiga.

5. Buka pintu bagian belakang kardus untuk melihat hasilnya.

6. Hitunglah jumlah batu yang ada di dalam kardus

Penerapan pembelajaran matematika menggunakan model PBL berbantuan media Tolkama dapat membangkitkan kesadaran belajar matematika peserta didik. Terjadi perubahan peningkatan pemahaman konsep dasar perkalian dan hasil belajar matematika peserta didik melalui kegiatan eksplorasi, elaborasi dan diskusi. Hal itu sesuai dengan pendapat Hamalik (2011:88) bahwa pembelajaran yang baik harus mampu mengantarkan peserta didik berubah perilaku menjadi lebih baik. Oleh karena itu, model pembelajaran PBL berbantuan media pembelajaran Tolkama direkomendasikan untuk diterapkan dalam pembelajaran matematika materi perkalian di kelas II Sekolah Dasar karena dapat meningkatkan pemahaman peserta didik terkait konsep dasar perkalian dan meningkatnya hasil belajar matematika peserta didik. Selain itu, variasi pembelajaran ini membuat peserta didik lebih semangat dalam mengikuti pembelajaran. 


\section{Syailin Nichla Choirin Attalina dan Saidatul Irfana : Peningkatan Kemampuan Pemahaman Konsep Dasar Perkalian Dengan Menerapkan Model Pembelajaran ...}

Berdasarkan penelitian yang telah dilakukan oleh Yeni (2011) dengan judul "Pemanfaatan Benda-Benda Manipulatif untuk Meningkatkan Pemahaman Konsep Geometri dan Kemampuan Tilikan Ruang Siswa Kelas V Sekolah Dasar" dijelaskan bahwasannya penggunaan media pembelajaran yang berupa pemanfaatan benda-benda manipulatif terbukti meningkatkan pemahaman konsep dasar matematika pada materi geometri dan kemampuan tilikan ruang untuk peserta didik kelas V sekolah dasar. Sejalan dengan hal tersebut Sulastri (2016) dalam penelitiannya yang berjudul "Penerapan Pendekatan Kontekstual dalam Pembelajaran Matematika untuk Meningkatkan Pemahaman Konsep Matematis Siswa Sekolah Dasar" juga menunjukkan bahwasannya penggunaan model pembelajaranyang variatif sesuai dengan materi pembelajaran dan karakteristik peserta didik dapat meningkatkan pemahaman konsep dasar matematika pada peserta didik Sekolah Dasar. Rusmana dan Idha dalam penelitiannya yang berjudul "Efektivitas Penggunaan Media ICT Dalam Peningkatan Pemahaman Konsep Matematika" juga mengungkapkan bahwasannya penggunaan media ICT dapat meningkatkan pemahaman konsep dasar matematika untuk peserta didik Sekolah Dasar secara efektif.

Berdasarkan pendapat para ahli diatas dapat disimpulkan bahwasannya, penggunaan model pembelajaran berbantuan media pembelajaran dapat efektif dalam meningkatkan pemahaman konsep dasar matematika pada peserta didik tingkat sekolah dasar. Dalam penggunaan model dan media pembelajaran tentunya harus memperhatikan karakteristik dari peserta didik yang akan diajar, dan tentunya harus sesuai dengan materi yang diajar agar tidak mempersulit peserta didik. Karena itulah kami mengharapkan agar penggunaan model pembelajaran PBL berbantuan media TOLKAMA dapat meningkatkan pemahaman konsep dasar perkalian bagi peserta didik kelas 2 sekolah dasar.

\section{Simpulan}

Berdasarkan dengan hasil studi dokumentasi yang telah di temukan oleh peneliti, dan berdasarkan dengan teori yang telah dipaparkan dapat disimpulkan bahwasannya, penggunaan model pembelajaran berbantuan media pembelajaran dapat efektif dalam meningkatkan pemahaman konsep dasar matematika pada peserta didik utamanya untuk tingkat sekolah dasar. Karena itulah kami mengharapkan agar penggunaan model pembelajaran PBL berbantuan media 
Syailin Nichla Choirin Attalina dan Saidatul Irfana : Peningkatan Kemampuan Pemahaman Konsep Dasar Perkalian Dengan Menerapkan Model Pembelajaran ...

TOLKAMA dapat meningkatkan pemahaman konsep dasar perkalian bagi peserta didik kelas 2 sekolah dasar.

\section{DAFTAR PUSTAKA}

\section{Buku}

Hamalik,Omar. 2011. Proses Belajar Mengajar. Jakarta: Bumi Aksara.

Isjoni. 2013. Cooperative Learning. Bandung: Alfabeta.

Ngalimun. 2012. Strategi dan Model Pembelajaran. Yogyakarta: Aswaja Pressindo.

Rusman. 2013. Model-model Pembelajaran: Mengembangkan Profesionalisme Guru. Jakarta: PT. Raja Grafindo Persada.

Rayandra, Asyar. 2012. Kreatif Mengembangkan Media Pembelajran. Jakarta: Gaung Persada Press.

Wahidmurni. 2017. Metodologi Pembelajaran IPS. Yogyakarta: Ar-Ruzz Media.

\section{Jurnal}

Fahrudin, Ahmad Gilang dkk. 2018. Peningkatan Pemahaman Konsep Matematika Melalui Realistic Mathematic Education Berbantu Alat Peraga Bongpas. Jurnal Pendidikan Matematika. 1 (1): 16-20.

Febriyanto, Budi, dkk. 2018. Peningkatan Pemahaman Konsep Matematis Melalui Penggunaan Media Kantong Bergambar pada Materi Perkalian Bilangan Di Kelas II Sekolah Dasar. Jurnal Cakrawala Pendas. Vol 4. No 2.

Virgiana dan Wasitohadi. 2016. Efektivitas Model Problem Based Learning Berbantuan Media Audio Visual Ditinjau dari Hasil Belajar IPA Siswa Kelas 5 SDN 1 Gadu Sambong - Blora Semester 2 Tahun 2014/2015. Scholaria. $6(2): 100-118$.

Sulastri, Ai. 2016. Penerapan Pendekatan Kontekstual dalam Pembelajaran Matematika untuk Meningkatkan Pemahaman Konsep Matematis Siswa Sekolah Dasar. Jurnal Pendidikan Guru Sekolah Dasar. 1 (1): 156-170.

Rusman, Indra Martha dan Idha Isnaningrum. Efektivitas Penggunaan Media ICT Dalam Peningkatan Pemahaman Konsep Matematika. Jurnal Formatif 2(3): 198-205.

Yeni, Ety Mukhlesi. 2011. Pemanfaatan Benda-Benda Manipulatif untuk Meningkatkan Pemahaman Konsep Geometri dan Kemampuan Tilikan Ruang Siswa Kelas V Sekolah Dasar. No. 1: 63-75. 